\title{
Fertility in Soils Cultivated with Guava Tree in Calvillo, Aguascalientes, Mexico
}

\author{
De Luna Jiménez A*, Arredondo Figueroa José Luis, Rocha Ruíz JR, Luna Ruíz José de Jesús and \\ De Lara Martínez Jorge
}

Department of Agronomic Sciences, Benemérita Autonomous University of Aguascalientes, Mexico

*Corresponding author: De Luna Jiménez A, Center of Agricultural Sciences, Department of Agronomic Sciences, Benemérita Autonomous University of Aguascalientes, Mexico.

To Cite This Article: De Luna Jiménez A, Fertility in Soils Cultivated with Guava Tree in Calvillo, Aguascalientes, Mexico. 2020 - 7(5). AJBSR. MS.ID.001186. DOI: 10.34297/AJBSR.2020.07.001186.

Received: 眥 February 10, 2020; Published: 㘹 February 27, 2020

\begin{abstract}
In the gardens undernourished trees exist, they express physiological alterations associated with reduction of the yield and fruits of bad quality. The target of the investigation was to estimate the content of nutrients and its relation with the nutrition of the guava tree in Calvillo, Aguascalientes, Mexico. During the year 2017, there were selected 8 soils where the plants presented shortcoming symptoms, by means of the method in zigzag, 9 sampling places were located in every soil, sub-samples took to the 0-30, 30-60 and 60-90 cm depths., 9 sub-samples for depth, were mixed and by means of cuarteos successive a sample composed for its chemical analysis was obtained. The chemical variables that decided were: N, P, K, Faith, $\mathrm{Zn}$ and $\mathrm{Cu}$ in $\mathrm{mg} \mathrm{kg}^{-1}$. The results indicated than in $30 \mathrm{~cm}$., of thickness the content of $\mathrm{N}$ was 10.7, P 13.6, K 442, Faith 0.2 , Zn 0.4 and Cu 0.03 mg kg-1 respectively. In $60 \mathrm{~cm}$, the $\mathrm{N}$ was 4.2, P 10.6, K 422, Faith $0.2, \mathrm{Zn} 0.6$ and $\mathrm{Cu} 0.03 \mathrm{mg} \mathrm{kg}^{-1}$ correspondientemente and to $90 \mathrm{~cm}$., the $\mathrm{N}$ was 2.7 , P 5.6, $\mathrm{K} 480$, Faith 0.5 , Zn 0.3 and $\mathrm{Cu} 0.04 \mathrm{mg} \mathrm{kg}^{-1}$ mutually. Scarcity of the elements was therefore it is necessary to design a scheme of fertilization that allows to feed better to the plant and raise the production.
\end{abstract}

Keywords: Soil fertility; Nutrition of the guava tree; Chemical fertilization

\section{Introduction}

The fertility is the capacity that has the soil of providing the nutrients necessary for growth of the plant [1]. The chemical analysis allows to give pursuit to the soil fertility [2].The success of the analyses depends on the interpretation that is given him to the results [3]. The difference between supply and demand of the cultivation, it indicates the quantity of nutrients that must join by means of the fertilization [4]. To increase the yield, it is necessary to know the contribution of the soil and the requests of the plant [5]. Also, the interrelation of the chemical analysis with the answer of the cultivation and at the specific sufficiency level for the guava tree [2].This work was realized because trees exist with nutritional problems associated with low yield and fruits of bad quality. To increase the production, it is necessary to do a more efficient and sustainable handling of the available nutrients [6]. The soils are characterized for being arid and alkaline where it is feasible to detect micronutrients shortcomings, principally zinc and iron [7]. The micronutrients are in the chemical fractions: interchangeable, joined to the organic matter, ocluido in the carbonates and like component of the crystalline network [8]. The Zn shortcoming in the fruit trees is generalized [9] and the applications you will foliate they are part of the annual program of fertilization of the producer [2]. The changes in the contents of $\mathrm{Zn}$, Faith, and $\mathrm{Cu}$ comes from the alluvial materials or for contamination due to the use of fertilizers you will foliate [10]. The chemical fertilizers produce an acidic reaction in the soil altering the $\mathrm{pH}$ at level of rizósfera [4]. On the other hand, they cause a redistribution of the micronutrients between the fractions of the soil to forms more available for the plants [11]. The target of the investigation was to estimate the availability of N, P, K, Faith, $\mathrm{Zn}$ and $\mathrm{Cu}$ as regards the nutrition of the guava tree in Calvillo, Aguascalientes.

\section{Materials and Methods}

The municipality of Calvillo, there is in the part south-west of the state of Aguascalientes, is located between the $21051^{\prime}$ and 220 $43^{\prime} \mathrm{N}$; $102032^{\prime}$ and $102053^{\prime} \mathrm{W}$, to a height of $1630 \mathrm{msnm}$ it is 
provided with three climatic types; the moderate sub-humid one with rains in summer $(\mathrm{Cw})$, the semidry one - semicálido (BS1h) and the semidry - moderate one (BS1k) in proportions of 29.1, 35.2 and $35.7 \%$ respectively. The average temperature of the coldest month (January) is of $15.2^{\circ} \mathrm{C}$ and of the warmest month (June) of $24.1^{\circ} \mathrm{C}$; with an annual average temperature understood in the status of $18^{\circ} \mathrm{C}$ to $22^{\circ} \mathrm{C}$; between May and August the highest temperature registers. The annual average precipitation is 591.4 millimeters and evaporation is 1782.4 millimeters.

The soils belong to lomerío with irregular topography, they exhibit dependent on $320 \%$, the thickness of the arable layer is 10 $\mathrm{cm}$., they retain little water, the excesses cause water erosion and loss of nutrients, what collaborates with nutritional shortcomings in the plant and reduction of the yield. The domineering soils are regosoles, although also they are feozem, luvisol, litosol and planasol.

There were selected 8 soils where the plants presented visual shortcomings symptoms nutrimentales. In every soil by means of the method in zigzag, 9 sampling places were located, sub-samples were obtained to the $0-30,30-60$ and $60-90 \mathrm{~cm}$ depths., a sample composed for every depth was obtained, surrendering to chemical analysis. A design was used completely at random, considering the soils like treatments and the depths like repetitions. The chemical variables that decided were: $\mathrm{N}, \mathrm{P}$, and $\mathrm{K}$ in $\mathrm{mg} \mathrm{kg}^{-1}$ (I square 1) and Faith, $\mathrm{Zn}$, and $\mathrm{Cu}$ in mg kg-1 by means of DTPA and atomic absorption (square 2), (Figure 1).

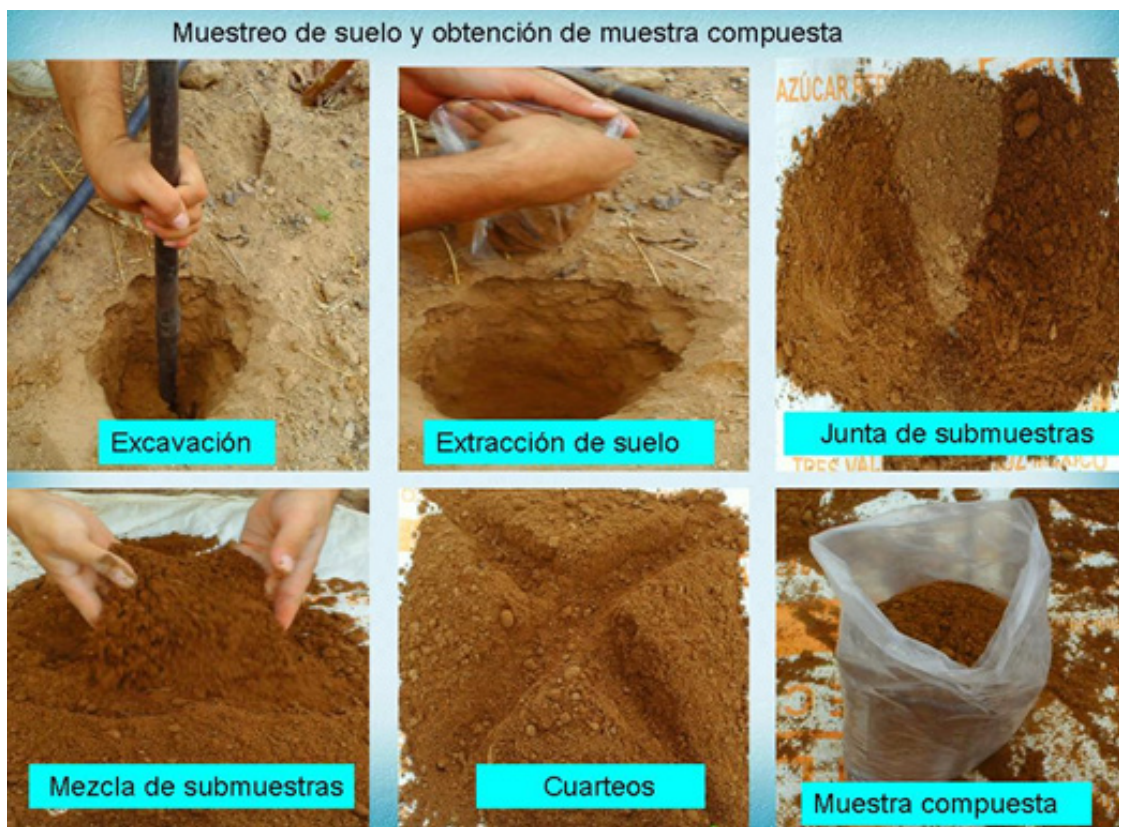

Square 1: Content of nitrogen, phosphorus and potassium $\left(\mathrm{mg} \mathrm{kg}^{-1}\right)$ in 8 soils and 3 depths.

\begin{tabular}{|c|c|c|c|c|c|c|c|c|c|c|c|c|}
\hline & \multicolumn{2}{|c|}{ Nitrógeno (10-22) } & & \multicolumn{3}{|c|}{ Fósforo (15-25) } & & \multicolumn{3}{c|}{ Potasio (175-280) } & \multicolumn{2}{|c|}{} \\
\hline Suelo & $\mathbf{3 0}$ & $\mathbf{6 0}$ & $\mathbf{9 0}$ & Promedio & $\mathbf{3 0}$ & $\mathbf{6 0}$ & $\mathbf{9 0}$ & Promedio & $\mathbf{3 0}$ & $\mathbf{6 0}$ & $\mathbf{9 0}$ & Promedio \\
\hline 1 & 17.3 & 3.7 & 2.1 & $7.7 \mathrm{ab}$ & 42.3 & 28.9 & 15.5 & $28.9 \mathrm{a}$ & 564 & 614 & 664 & $614 \mathrm{a}$ \\
\hline 2 & 12 & 1.4 & 0.9 & $4.8 \mathrm{ab}$ & 28.9 & 44.6 & 24.5 & $32.7 \mathrm{a}$ & 392 & 312 & 399 & $367 \mathrm{bc}$ \\
\hline 3 & 7.5 & 1.1 & 0.9 & $3.2 \mathrm{~b}$ & 17.8 & 6.6 & 0.9 & $8.4 \mathrm{~b}$ & 417 & 291 & 275 & $327 \mathrm{c}$ \\
\hline 4 & 15.5 & 10.2 & 8.4 & $11.4 \mathrm{a}$ & 15.5 & 1.2 & 1.2 & $6.0 \mathrm{~b}$ & 414 & 480 & 454 & $449 \mathrm{ab}$ \\
\hline 5 & 8.4 & 7.1 & 3.9 & $6.5 \mathrm{ab}$ & 2.1 & 1.2 & 1.2 & $1.5 \mathrm{~b}$ & 472 & 419 & 473 & $454 \mathrm{abc}$ \\
\hline 6 & 10.2 & 1.6 & 1.1 & $4.3 \mathrm{~b}$ & 2.1 & 0.9 & 0.3 & $1.1 \mathrm{~b}$ & 522 & 410 & 575 & $502 \mathrm{ab}$ \\
\hline 7 & 7.5 & 7.1 & 3.4 & $6.0 \mathrm{ab}$ & 1.2 & 1.2 & 0.9 & $1.1 \mathrm{~b}$ & 358 & 396 & 502 & $418 \mathrm{bc}$ \\
\hline 8 & 7.1 & 1.8 & 1.1 & $3.3 \mathrm{~b}$ & 0.9 & 0.3 & 0.3 & $0.5 \mathrm{~b}$ & 395 & 453 & 497 & $448 \mathrm{abc}$ \\
\hline $\begin{array}{c}\text { Prome- } \\
\text { dio }\end{array}$ & 10.7 & 4.2 & 2.7 & & 13.6 & 10.6 & 5.6 & & 442 & 422 & 480 & \\
\hline Sig. & $* *$ & $* *$ & $* *$ & $*$ & $\mathrm{~ns}$ & $\mathrm{~ns}$ & $\mathrm{Ns}$ & $* *$ & $\mathrm{~ns}$ & $\mathrm{~ns}$ & Ns \\
\hline
\end{tabular}

30,60 and $90 \mathrm{~cm}$, = Sampling depths, $\mathrm{N}\left(\mathrm{mg} \mathrm{kg}^{-1}\right)=$ Vapor drag with $\mathrm{MgO}$ and Devarda Alloy, $\mathrm{P}\left(\mathrm{mg} \mathrm{kg}^{-1}\right)=$ Olsen, $\mathrm{K}(\mathrm{mg} \mathrm{kg}-1)=\mathrm{Acetate}$ Ammonium $1 \mathrm{~N} \mathrm{pH} 7$ and atomic absorption. ${ }^{*}=$ Significant difference $(P<0.05) ;{ }^{* *}=$ Highly significant difference $(P<0.01)$; ns $=$ not significant $(P>0.05)$. Averages followed with the same letter are statistically equal Tukey, $\alpha=0.05$ 


\section{Results and Discussion}

The nitrogen diminished with the depth, this behavior has relation with the mineralization of the MO, as it is indicated by Ankenbauer KJ [12], what does that the nitrogen in the soil is available for the plants [9].The average of three depths, from 3.2 to 11.4 is in the status $\mathrm{mg} \mathrm{kg}^{-1}$ (I square 1 ). The variance analysis pointed out that there exist significant differences $(\mathrm{P}<0.05)$ in the nitrogen content between the soils and between depths (P $<0.01$ ). The grouping of the soils as Tukey, $\alpha=0.05$, indicated that the soil 4 , is that of major content of nitrogen (a), the group followed him (ab) integrated by the soils 1,2,5 and 7 and finally the group (b) to that the soils belong 3, 6 and 8 (square 1).

The phosphorus average in three depths, finds in the status from 0.5 to $28.9 \mathrm{mg} \mathrm{kg}^{-1}$ (I square 1). The variance analysis expressed that between soils there exist highly significant differences $(\mathrm{P}<0.01)$, while in depth it turned out to be equal $(\mathrm{P}>0.05)$, this result agrees with the brought for [13]. The Tukey test, $\alpha=0.05$, distinguishes two groups; the group (a) with the soils 1 and 2, with equal quantity between themselves but with the highest content with regard to other soils and the group (b) integrated by the soils insignificant 3 , $4,5,6,7$ and 8.

In average the potassium quantity, from 327 to 614 is in the status $\mathrm{mg} \mathrm{kg}^{-1}$ (I square 1 ). The variance analysis concluded that between soils there exist notable differences $(\mathrm{P}<0.01)$, while in depths they do not exist $(\mathrm{P}>0.05)$. In accordance with the test of comparison of averages of Tukey, $\alpha=0.05$, the grouping indicates than to the group (a) the soil belongs 1 ; to the group (ab), the soils 4 and 6; to the group (bc) the soils 2 and 7; to the group (abc) the soils 5 and 8 and finally to the group (c) the soil 3 (I Square 1).

The variance analysis for Faith, $\mathrm{Zn}$ and $\mathrm{Cu}$, detected difference ( $P>0.05)$ neither in soils nor in depths, the quantities are similar (I square 2).

(I Square 2)

\begin{tabular}{|c|c|c|c|c|c|c|c|c|c|c|c|c|}
\hline \multirow[b]{2}{*}{ Suelo } & \multicolumn{3}{|c|}{ Fierro (2.5-5) } & \multirow[b]{2}{*}{ Prom } & \multicolumn{3}{|c|}{ Zinc $(>1.5)$} & \multirow[b]{2}{*}{ Prom } & \multicolumn{3}{|c|}{ Cobre $(>2)$} & \multirow[b]{2}{*}{ Prom } \\
\hline & 30 & 60 & 90 & & 30 & 60 & 90 & & 30 & 60 & 90 & \\
\hline 1 & 0.2 & 0.3 & 0.1 & $0.22 \mathrm{a}$ & 0.5 & 0.4 & 0.3 & $0.4 \mathrm{a}$ & 0.02 & 0.02 & 0.02 & $0.02 \mathrm{a}$ \\
\hline 2 & 0.1 & 0.2 & 0.1 & $0.13 a$ & 0.5 & 0.4 & 0.2 & $0.4 \mathrm{a}$ & 0.02 & 0.02 & 0.17 & $0.07 \mathrm{a}$ \\
\hline 3 & 0.1 & 0.1 & 0.1 & $0.10 \mathrm{a}$ & 0.3 & 2.2 & 0.2 & $0.9 \mathrm{a}$ & 0.05 & 0.02 & 0.05 & $0.04 \mathrm{a}$ \\
\hline 4 & 0.1 & 0.3 & 0.1 & $0.17 \mathrm{a}$ & 0.4 & 0.3 & 0.3 & $0.3 \mathrm{a}$ & 0.1 & 0.05 & 0.15 & $0.10 \mathrm{a}$ \\
\hline 5 & 0.4 & 0.5 & 0.8 & $0.57 \mathrm{a}$ & 0.5 & 0.6 & 0.5 & $0.5 \mathrm{a}$ & 0.03 & 0.02 & 0.1 & $0.05 \mathrm{a}$ \\
\hline 6 & 0.4 & 0 & 0 & $0.13 a$ & 0.3 & 0.2 & 0.3 & $0.3 \mathrm{a}$ & 0.02 & 0.05 & 0.02 & $0.03 \mathrm{a}$ \\
\hline 7 & 0.3 & 0 & 1.1 & $0.47 \mathrm{a}$ & 0.4 & 0.3 & 0.3 & $0.3 \mathrm{a}$ & 0.02 & 0.02 & 0.05 & $0.03 \mathrm{a}$ \\
\hline 8 & 0.2 & 0.4 & 1.4 & $0.67 \mathrm{a}$ & 0.2 & 0.2 & 0.3 & $0.2 \mathrm{a}$ & 0.02 & 0.02 & 0.02 & $0.02 \mathrm{a}$ \\
\hline Prom. & 0.2 & 0.2 & 0.5 & & 0.4 & 0.6 & 0.3 & $0.4 \mathrm{a}$ & 0.03 & 0.03 & 0.07 & $0.04 \mathrm{a}$ \\
\hline Sig. & ns & ns & ns & ns & ns & ns & ns & ns & ns & ns & ns & ns \\
\hline
\end{tabular}

$\mathrm{Fe}, \mathrm{Zn}$ and $\mathrm{Cu}$ in $\mathrm{mg} \mathrm{kg-1}$ respectively with DTPA and atomic absorption.ns = Not significant Averages followed with the same letter are testadísicamente equal Tukey, $\alpha=0.05$.

\section{Conclusions}

The soils contain insufficient quantities of nutrients to satisfy the requests of the guava tree. The strategy must center on optimizing the balance of the $\mathrm{N}$ in the soil increasing the earnings and diminishing the exits.

After the $\mathrm{N}$, the $\mathrm{P}$, it is the element that in major measurement limits the yield. The plants absorb the $\mathrm{P}$ of the solution of the soil therefore its loss must diminish for erosion, surface washing and lixiviación. The main sources of $\mathrm{K}$ interchangeable sound the clays and the mineralization of the organic residues [14]. The distribution of the Faith, $\mathrm{Zn}$ and Cu extraíbles with DTPA in the soils is explained by the organic matter accumulation in surface and recycling of mineral elements. To improve the nutrition of the plant, it is necessary to define a subscriber's program, complemented with chemical fertilizer.

\section{References}

1. Rosemary F, Vitharana UWA, Indraratne SP, Weerasooriya R, Mishra U (2017) Exploring the spatial variability of soil properties in an Alfisol soil catena. Catena 150: 53-61.

2. Sharma A, Wali VK, Bakshi P, Jasrotia A (2013) Effect of integrated nutrient management strategies on nutrient status, yield and quality of guava. Indian Journal of Horticulture 70(3): 333-339.

3. Gloaguen TV, Pereira FAD, Goncalves RAB, Paz VD (2009) Chemical Composition of Soil Solution in Different Soil Pore Classes. Revista Brasileira De Ciencia Do Solo 33(5): 1105-1113.

4. Nietfeld H, Prenzel J, Helmisaari HS, Polle A, Beese F (2017) Modeling of mineral nutrient uptake of spruce tree roots as affected by the ion dynamics in the rhizosphere: Upscaling of model results to field plot scale. Ecological Modelling 345: 150-164. 
5. Ram RA, Singha A, Bhriguvanshi SR (2014) Response of on farm produced organic inputs on soil, plant nutrient status, yield and quality of guava (Psidium guajava) cv Allahabad Safeda. Indian Journal of Agricultural Sciences 84(8): 962-967.

6. Swain SC, Padhi SK (2012) Changes In Growth Characters And Nutrient Acquisition Of Guava (Psidium guajava L.) IN RESPONSE TO COAL ASH. Pakistan Journal of Agricultural Sciences 49(3): 261-265.

7. Prado RD, Natale W (2004) Effect of the liming on the nutrition and the development of the guava root system. Pesquisa Agropecuaria Brasileira 39(10): 1007-1012.

8. Sawicka B, Barbas P, Skiba D (2016) Fluctuations of Sodium, Copper Zinc, Iron and Manganese In Potato Tubers in the Organic and Integrated Production System. Journal of Elementology 21(2): 539-547.

9. Bangira C, Deng YJ, Loeppert RH, Hallmark CT, Stucki JW (2011) Soil Mineral Composition in Contrasting Climatic Regions of the Great Dyke, Zimbabwe. Soil Science Society of America Journal 75(6): 2367-2378.

10. Morikawa CK, Saigusa M, Nakanishi H, Nishizawa NK, Mori S (2006) Overcoming Fe deficiency in guava (Psidium guajava L.) by co-situs application of controlled release fertilizers. Soil Science and Plant Nutrition 52(6): 754-759.

11. Schenkeveld WDC, Kimber RL, Walter M, Oburger E, Puschenreiter M, et al. (2017) Experimental considerations in metal mobilization from soil by chelating ligands: The influence of soil-solution ratio and preequilibration - A case study on Fe acquisition by phytosiderophores. Science of the Total Environment 579: 1831-1842.

12. Ankenbauer KJ, Loheide SP (2017) The effects of soil organic matter on soil water retention and plant water use in a meadow of the Sierra Nevada, CA. Hydrological Processes 31(4): 891-901.

13. Turner BL, Engelbrecht BMJ (2011) Soil organic phosphorus in lowland tropical rain forests. Biogeochemistry 103(1-3): 297-315.

14. Roveda LF, Cuquel FL, Motta ACV, Melo VD (2016) Organic compounds with high Ni content: Effects on soil and strawberry production. Revista Brasileira De Engenharia Agricola E Ambiental 20 (8): 722-727. 